\title{
Numerical Simulation of the Process of Combustion of a Stoichiometric Hydrogen-Oxygen Mixture in a Steam Generator
}

\author{
Andrii N. Avramenko \\ A. Podgorny Institute for Mechanical Engineering Problems of the National Academy of Sciences \\ of Ukraine, Str. Pozharskogo, 2/10, 61046 Kharkiv, Ukraine, \\ Kharkiv National Automobile and Highway University, Kharkov, Ukraine.
}

\section{an0100@ukr.net}

Keywords: hydrogen combustion, numerical methods, turbulence model, burner, hydrogen-oxygen mixtures

Numerical methods are used to study the process of combustion of a stoichiometric hydrogen-oxygen mixture. The mathematical models were validated using experimental data. The combustion process is modelled in the three-dimensional unsteady formulation. With account of the recommendations of other authors, the turbulent flows are described in the paper using the standard $k-\varepsilon$ turbulence model. The Eddy Dissipation Model (EDM) is used to describe the process of combustion of the hydrogenoxygen mixture. The description of the complex heat transfer between the gas, flame and walls in the paper accounts for radiant heat transfer by using the P1 model. The paper deals with combustion processes in a burner and a model steam generator. Numerical methods were used to evaluate the effect of inlet flow turbulisation, and the flow rate and the method of feeding extra water to the combustion chamber on the process of combustion of the stoichiometric hydrogen-oxygen mixture. The influence of the design and operating mode factors on the alteration of the flame-steam interface and on the flame extinguishing conditions were studied. The results obtained can be used in future in designing equipment that uses hydrogen as a fuel to increase nuclear power plant (NPP) manoeuvrability.

\section{Introduction}

Hydrogen is a promising eco-friendly fuel for power systems [1-3] and it has a significant potential (it can be used in direct firing, e.g., in burners and an internal combustion engine [1-10], and oxidized on the anode in fuel cells [11]).
The process of hydrogen combustion in oxygen excludes the formation of toxic components, and hydrogen can be used as a fuel in the auxiliary steam generator in a thermal or nuclear power plant [12-15].

The authors of the papers $[16,17]$ studied the kinetics of chemical reactions during the combustion of hydrogen-oxygen mixtures. 
Publication [16] considers the formulation of a chemical reaction, and the mechanisms and the process of setting up chemical rate equations from stoichiometric data and elementary reaction rates.

The authors of [17] showed that an optimized hydrogen combustion mechanism provides the most suitable description of the ignition delay time and laminar flame speed, with this being in good agreement with experimental data.

Paper [18] dealt with optimisation of hydrogen combustion mechanisms and synthesis gas; the covariance matrix of the optimised parameters was calculated, and temperaturedependent uncertainty ranges were obtained for the rate coefficients of each of the optimised reactions.

Paper [19] performed a comparison and analysis of the performance of several hydrogen combustion mechanisms. An approach was considered to exclude those measurements that none of the mechanisms could reproduce within a predefined uncertainty.

An analysis of sensitivity coefficients was carried out to identify reactions and ranges of conditions that require more attention in the future development of hydrogen combustion models.

Paper [20] examined chemical modelling and its influence on the transition of combustion conditions from deflagration to detonation. It was shown that, in the case of hydrogen-air mixtures, the multi-step chemical description is far more restrictive than the single-step model when it comes to the necessary conditions for a hot spot to lead to detonation.

The authors of [21] used experimental and numerical methods for a slot burner to study the effect of enrichment with hydrogen and addition of steam on the speed of the laminar flame of preliminarily mixed methane and air. The results showed that enrichment with hydrogen increased the laminar combustion rate and the flame adiabatic temperature. The addition of steam to a methane-air mixture noticeably decreased the burning rate and the adiabatic flame temperature.

A specific feature of operation of thermal and nuclear power plants is their cyclic load period [22]. This calls to look for ways to increase their manoeuvrability by accumulating extra energy during slack hours and returning the accumulated energy during peak load hours [14, $15]$.

One of the ways of increasing the manoeuvrability of thermal and nuclear power plants is accumulating extra energy by separately generating hydrogen and oxygen using the water electrolysis method [23], followed by their storage in high-pressure cylinders and further combustion in an auxiliary steam generator installed, for instance, in the steam turbine intermediate pressure stage $[14,15]$.

It is known that hydrogen, as a fuel, as compared with other combustible gases, has a 
number of significant advantages: a high combustion heat and rate, wide ignition concentration ranges and a low activation energy [14].

During combustion of the stoichiometric hydrogen-oxygen mixture, the temperature in the flame zone reaches $3,000{ }^{\circ} \mathrm{C}[14,15]$, with superheated steam being generated in the steam generator flow part with a temperature of 1,000$1,500{ }^{\circ} \mathrm{C}[15]$. This makes hydrogen a promising fuel for use in the steam generators of thermal and nuclear power plants.

Problems related to investigating the following have been poorly studied to date: the process of hydrogen combustion in oxygen by using numerical methods; designing combustion chambers (CC) with an enhanced combustion efficiency, especially during transition operating conditions; reliable cooling of thermally stressed $\mathrm{CC}$ parts and reduced heat loss to the environment.

Issues related to the following have been poorly studied to date: the effect of turbulising insert elements at the inlet of the hydrogenoxygen steam generator on the processes of combustion and formation of reaction products.

The paper uses numerical methods to evaluate the effect of inlet flow turbulisation, and the flow rate and method of feeding extra water to the combustion chamber on the processes of combustion of the stoichiometric hydrogenoxygen mixture.

\section{Materials and methods}

The paper considers the process of combustion of a stoichiometric hydrogen-oxygen mixture in the three-dimensional unsteady problem statement. The research structure is shown in Fig. 1.

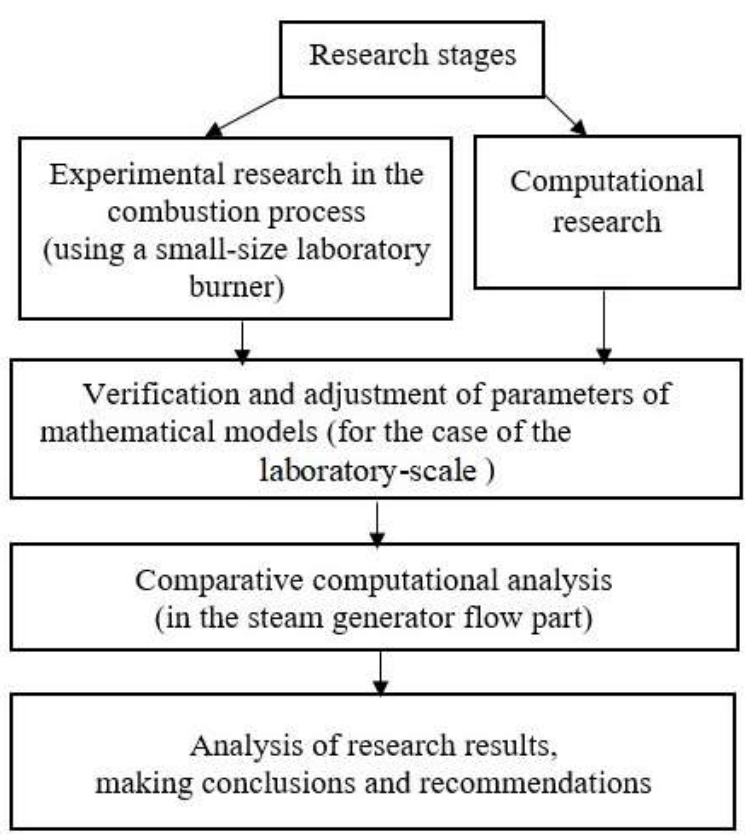

Figure 1. The research structural diagram

\section{Experimental part}

The schematic diagram of the experimental setup is shown in Fig. 2.

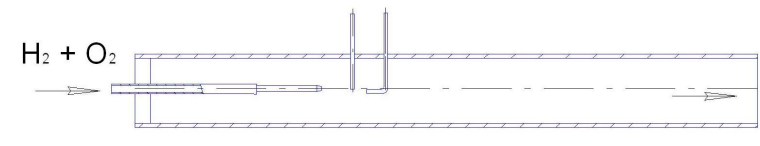

Figure 2. Schematic diagram of the experimental setup

Hydrogen and oxygen were generated using an alkali electrolyser, and the gases were cleaned of steam with a separator.

The following parameters were monitored during the experiment: the hydrogenoxygen mixture flow rate and temperature; the waste gases composition (with a gas analyser) 
and the waste gases temperature (with a chromelalumel thermocouple in the stagnated flow), Fig.

3.

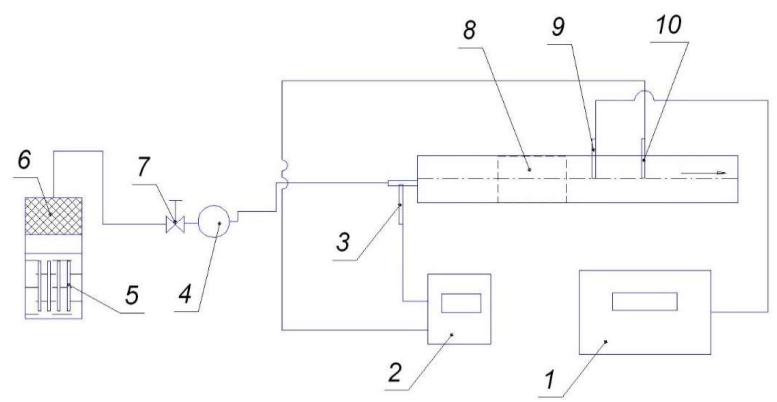

1 - gas analyser; 2 - temperature recording instrument; 3 - gas mixture temperature sensor; 4 - gas flow meter; 5 - electrolyser; 6 - separator; 7 - valve; 8 - burner; 9 - sampler; 10 - waste gases temperature sensor.

Figure 3. Experimental setup diagram

The authors [24] investigated the changes in the flame length, the lift-off height, the temperature, the flame composition and the emission indices of the species in the post-flame region for a turbulent flame of a methane-air stream without preliminary mixing. The suggested research technique enabled to evaluate changes in the flame geometry, the reduction in flame temperature and the reduction in $\mathrm{NO}_{\mathrm{x}}$ concentration at various levels of dilution of carbon dioxide in the fuel.

The combustion of the hydrogen-oxygen mixture (primary reaction) is considered with account of 15 intermediate reactions (Table 1) $[16,17,25]$.

Primary reaction:

$$
\mathrm{H}_{2}+1 / 2 \mathrm{O}_{2}=\mathrm{H}_{2} \mathrm{O}+241
$$

In the paper, the turbulent flows were described with account of recommendations in

[26-28], and the standard $k-\varepsilon$ model [29-31] turbulence model was used.

The standard $k-\varepsilon$ model equations have the form [32]:

$$
\begin{gathered}
\frac{\partial}{\partial t}(\rho \cdot k)+\frac{\partial}{\partial x_{i}}\left(\rho \cdot k \cdot \bar{u}_{i}\right)=\frac{\partial}{\partial x_{j}}\left[\left(\mu+\frac{\mu_{t}}{\sigma_{k}}\right) \frac{\partial k}{\partial x_{j}}\right]+ \\
+G_{k}+G_{b}-\rho \cdot \varepsilon-Y_{M}+S_{k}, \\
\frac{\partial}{\partial t}(\rho \cdot \varepsilon)+\frac{\partial}{\partial x_{i}}\left(\rho \cdot \varepsilon \cdot \bar{u}_{i}\right)=\frac{\partial}{\partial x_{j}}\left[\left(\mu+\frac{\mu_{t}}{\sigma_{\varepsilon}}\right) \frac{\partial \varepsilon}{\partial x_{j}}\right]+ \\
+G_{1 \varepsilon} \frac{\varepsilon}{k}\left(G_{k}+C_{3 \varepsilon} \cdot G_{b}\right)-C_{2 \varepsilon} \cdot \rho \frac{\varepsilon^{2}}{k}+S_{\varepsilon},
\end{gathered}
$$

$\mathrm{k}$ is the specific kinetic turbulent energy; $\varepsilon$ is the rate of the viscous dissipation of turbulent energy; $\rho$ is the gas density; $\mu_{t}$ is the turbulent dynamic viscosity; $\bar{u}_{i}$ is the averaged velocity; $\sigma_{k}$ is a dimensionless empirical constant; $G_{k}$ is the turbulent kinetic energy formed by mean velocity gradients; $G_{b}$ is the displacement force kinetic energy; $C_{3 \varepsilon}=1$ (for liquid layers, with the liquid velocity direction being parallel to the gravitation vector), $C_{3 \varepsilon}=0, C_{3 \varepsilon}=1$ (for liquid layers, with the liquid velocity direction being perpendicular to the gravitation vector), $C_{2 \varepsilon}=1.92, C_{1 \varepsilon}=1.44$ are constants [32, 33]; $Y_{M}$ is the contribution of the variable expansion during compression turbulence to the total dissipation rate; $S_{k}$ is the invariant of the strain tensor. 
FRENCH-UKRAINIAN JOURNAL OF CHEMISTRY (2021, VOLUME 09, ISSUE 02)

Table 1. Intermediate reactions with participation of $\mathrm{O}_{2}, \mathrm{O}$ and $\mathrm{OH}$ in reacting mixtures $\left(\mathrm{H}_{2}+\mathrm{O}_{2}+\right.$ inert gas)

\begin{tabular}{|c|c|c|}
\hline № & Reactions & $k_{r}^{0}(T),\left(\right.$ in $\mathrm{cm}^{3}$, mole,$\left.s\right)$ \\
\hline 1 & $\mathrm{HO}_{2}+\mathrm{H}_{2} \leftrightarrow \mathrm{OH}^{*}+\mathrm{H}_{2} \mathrm{O}$ & $3.0 \cdot 10^{15} \cdot(T / 298)^{-1.7} \cdot \exp (-1900 / T)$ \\
\hline 2 & $O^{*}+H+M \leftrightarrow O H^{*}+M$ & $7.0 \cdot 10^{15} \cdot(T / 298)^{-1}$ \\
\hline 3 & $O+H+M \leftrightarrow O H^{*}+M$ & $1.0 \cdot 10^{16} \cdot(T / 298)^{-1} \cdot \exp (-1200 / T) ; M=O H: 2.0 \cdot 10^{15} \cdot(T / 298)^{-1}$ \\
\hline 4 & $O H^{*}+M \leftrightarrow O H+M$ & $\begin{array}{l}M=H_{2} O: 2.2 \cdot 10^{14} \cdot \exp (-276 / T) \\
H_{2}: 1.0 \cdot 10^{12} ; \\
M=O_{2}: 6.0 \cdot 10^{12} ; \text { Ar: } 1.3 \cdot 10^{11} \cdot(T / 298)^{0.5}\end{array}$ \\
\hline 5 & $\mathrm{OH}^{*}+\mathrm{O}_{2} \leftrightarrow \mathrm{O}_{3}+H$ & $4.0 \cdot 10^{13} \cdot(T / 298)^{0.5}$ \\
\hline 6 & $\mathrm{OH}^{*}+\mathrm{H}_{2} \mathrm{O} \leftrightarrow \mathrm{H}_{2} \mathrm{O}_{2}+\mathrm{H}$ & $7.5 \cdot 10^{12} \cdot \exp (-276 / T)$ \\
\hline 7 & $\mathrm{OH}^{*}+\mathrm{H}_{2} \rightarrow \mathrm{H}_{2} \mathrm{O}+\mathrm{H}$ & $8.8 \cdot 10^{13} \cdot(T / 298)^{0.5}$ \\
\hline 8 & $\mathrm{OH}^{*}+\mathrm{O}_{2} \rightarrow \mathrm{HO}_{2}+\mathrm{O}$ & $2.0 \cdot 10^{13} \cdot(T / 298)^{0.5}$ \\
\hline 9 & $O H^{*} \rightarrow O H+h v$ & $1.4 \cdot 10^{6}$ \\
\hline 10 & $\mathrm{HO}_{2}+\mathrm{H} \rightarrow \mathrm{H}_{2} \mathrm{O}+\mathrm{O}^{*}$ & $2.3 \cdot 10^{13} \cdot(T / 298)^{0.458} \cdot \exp (-678 / T)$ \\
\hline 11 & $\mathrm{O}^{*}+\mathrm{H}_{2} \leftrightarrow \mathrm{OH}+\mathrm{H}$ & $\approx 1 \cdot 10^{14} \cdot \exp (-20000 / T)$ \\
\hline 12 & $\mathrm{O}^{*}+\mathrm{H}_{2} \rightarrow \mathrm{H}_{2} \mathrm{O}$ & $\approx 1 \cdot 10^{14}$ \\
\hline 13 & $O^{*}+M \leftrightarrow O+M$ & $\begin{array}{l}M=H_{2}: 1.0 \cdot 10^{14} ; O_{2}: 2.0 \cdot 10^{11} \\
A r: 2.0 \cdot 10^{11}\end{array}$ \\
\hline 14 & $\mathrm{H}+\mathrm{HO}_{2} \leftrightarrow \mathrm{H}_{2}+\mathrm{O}_{2}^{*}$ & $6.5 \cdot 10^{11} \cdot(T / 298)^{1.671} \cdot \exp (-3162 / T)$ \\
\hline 15 & $O_{2}^{*}+M \leftrightarrow O_{2}+M$ & $M=H_{2}: 2.7 \cdot 10^{6} ; O_{2}: 1.0 \cdot 10^{6} ; \mathrm{Ar}: 3.0 \cdot 10^{5}$ \\
\hline
\end{tabular}


The turbulent flows of gases during perturbation by the water spray were described using the standard $k-\varepsilon$ turbulence model, and that of water was described using the dispersed phase zero equation.

Basic model equations:

$$
v_{t d}=\frac{v_{t c}}{\sigma} \Rightarrow \mu_{t d}=\frac{\rho_{d}}{\rho_{c}} \cdot \frac{\mu_{t c}}{\sigma}
$$

The parameter $\sigma$ is the turbulent Prandtl number relating the dispersed phase kinematic eddy viscosity $U_{t d}$ to the continuous kinematic viscosity $U_{\text {tc. }}$

The conditions of evaporation of water droplets in interacting with gas were described by the Particle model. The Particle model for interfacial transfer between two phases assumed that one of the phases is continuous (phase $\alpha$ ) and the other is dispersed (phase $\beta$ ). The surface area per unit volume is then calculated by assuming that phase $\beta$ is present as the spherical of mean diameter $\mathrm{d}_{\beta}$.

The interphase contact area is:

$$
A_{\alpha \beta}=\frac{6 r_{\beta}}{d_{\beta}}
$$

The Euler-Euler multiphase model [3436] was used to describe the motion of the twophase flow in the steam generator flow part. The principal model equations are given below:

$$
\frac{\partial\left(\alpha_{k} \rho_{k}\right)}{\partial t}+\nabla \cdot\left(\alpha_{k} \rho_{k} \vec{u}_{k}\right)=\Gamma_{k}
$$

$$
\begin{aligned}
& \frac{\partial\left(\alpha_{k} \rho_{k} \vec{u}_{k}\right)}{\partial t}+\nabla \cdot\left(\alpha_{k} \rho_{k} \vec{u}_{k} \vec{u}_{k}\right)= \\
& =-\alpha_{k} \nabla p_{k}+\nabla \cdot \alpha_{k} \vec{\tau}_{k}+\alpha_{k} \rho_{k} \vec{g}+\vec{M}_{k},
\end{aligned}
$$

$\alpha_{k}$ is the volume fraction; $\Gamma_{k}$ describes the mass transfer between phases; $\vec{\tau}_{k}$ is the stress tensor of the 'kth' phase; $\vec{M}_{k}$ describes the interfacial forces acting on the ' $k$ th' phase due to the presence of the other phases.

The Eddy Dissipation Model (EDM) [37, 38] was used for describing the combustion process:

$\rho S_{Y}=A v_{k r}^{\prime} M_{w} \rho \frac{\varepsilon}{k} \min \left(\frac{Y_{R}}{v_{R, r}^{\prime} M_{w, r}}, B \frac{\sum_{p} Y_{p}}{\sum_{i}^{N} v_{l, r}^{\prime} M_{w, r}}\right)$, where $v_{k r}^{\prime}$ is the reaction stoichiometric coefficient, $Y_{R}$ is the mass fraction of the particular reactant species $\left(\mathrm{H}_{2}\right)$ and $Y_{p}$ is the mass fraction of the product species $\left(\mathrm{H}_{2} \mathrm{O}\right)$. The model constants are $\mathrm{A}=4.0$ and $\mathrm{B}=0.5$.

The description of the complex heat transfer between the gas, flame and walls in the paper accounts for radiant heat transfer by using the P1 model [29, 33, 38]. The equation of the P1 radiant heat transfer model has the form:

$$
q_{\Gamma}=-\frac{1}{3\left(\alpha+\sigma_{s}\right)-C \sigma_{s}} \cdot \nabla G,
$$

where $\alpha$ is the absorption coefficient, $\sigma_{s}$ is the scattering coefficient, $G$ is the incident radiation, 
$C$ is the linear-anisotropic phase function coefficient.

The spectral incident radiation:

$$
\nabla \cdot\left(\frac{1}{3\left(K_{a v}-K_{v s}\right)-A K_{v s}} \nabla G_{v}\right)=K_{a v}\left(G_{v}-4 E_{b v}\right),
$$

where A is the linear anisotropy coefficient.

The boundary condition at the walls is:

$$
\begin{aligned}
& n \cdot q_{r v}=-\frac{1}{3\left(K_{a v}-K_{v s}\right)-A K_{v s}} \frac{\partial G_{v}}{\partial n^{+}}= \\
& =\frac{\varepsilon_{v}}{2\left(2-\varepsilon_{v}\right)}\left[4 E_{b v}-G_{v}\right]_{w},
\end{aligned}
$$

where $\mathrm{n}$ is the unit vector outward normal to the wall; $\mathrm{n}+$ is the distance coordinate in the same direction, representing the value at the wall.

Next, the parameters of the mathematical models were verified and adjusted to describe the process of combustion of the stoichiometric hydrogen-oxygen mixture in a laboratory-scale burner with a simplified flow part geometry.

Fig. 4 is the photograph of combustion of the stoichiometric hydrogen-oxygen mixture in the laboratory-scale burner.

The flame colour changes from yellow to red owing to the burn-off of metal particles (nozzle material - stainless steel) that occurs during hydrogen and oxygen flow. This effect was not account for in the computations.

Table 2 shows the experimental results.

Fig. 5 illustrates the results of unsteady numerical simulation of the process of combustion of the hydrogen-oxygen mixture.
The maximum flame temperature reaches 3,000 ${ }^{\circ} \mathrm{C}$ (Fig. 5). With distance from the nozzle, the flame temperature drops from 2,400 to 800 ${ }^{\circ} \mathrm{C}$. The flame geometric characteristics (Fig. 5) are in good agreement with the results of the conducted experiment (Fig. 4) and Table 2.

Table 2 shows the comparison of computational and experimental results.

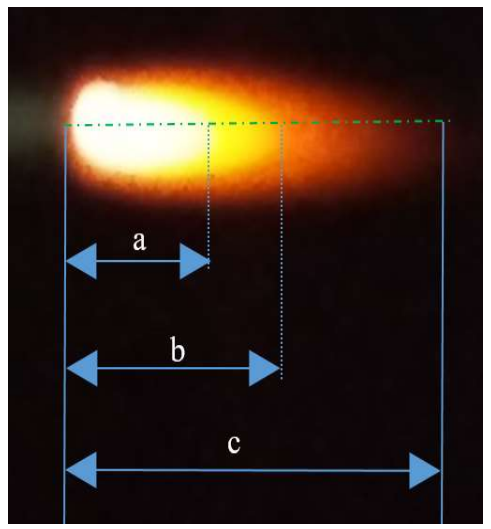

Figure 4. Photograph of combustion of the stoichiometric hydrogen-oxygen mixture (in air)

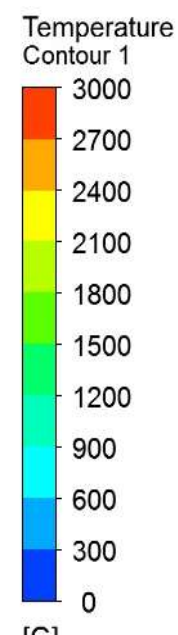

[C]

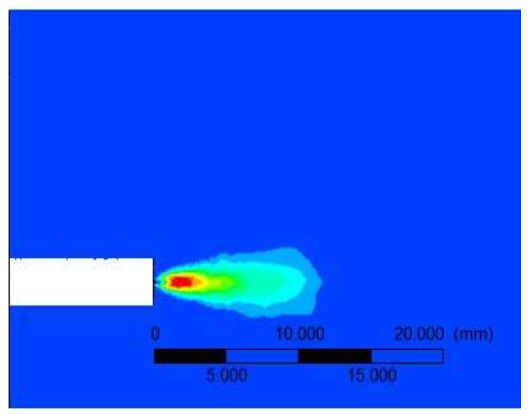

Figure 5. Distribution of instant flame temperature during combustion of the hydrogen-oxygen mixture 
Table 2. Comparison of experimental and computational results

\begin{tabular}{|l|c|c|c|c|c|}
\hline Results & \multicolumn{3}{|c|}{ Flame size, $\mathrm{mm}$} & $\begin{array}{c}\text { Temp- } \\
\text { erature }\end{array}$ & $\begin{array}{c}\text { NO } \\
\text { concent- } \\
\text { ration }\end{array}$ \\
\cline { 2 - 6 } & $\mathrm{a}$ & $\mathrm{b}$ & $\mathrm{c}$ & ${ }^{\circ} \mathrm{C}$ & $\mathrm{ppm}$ \\
\hline $\begin{array}{l}\text { Expe- } \\
\text { riment }\end{array}$ & 4.6 & 6.5 & 10 & 950 & 340 \\
\hline $\begin{array}{l}\text { Compu- } \\
\text { tation }\end{array}$ & 4.7 & 6.1 & 11 & 960 & 327 \\
\hline $\begin{array}{l}\text { Error } \\
\text { percentage }\end{array}$ & 2.17 & 6.15 & 10 & 1.05 & 3.8 \\
\hline
\end{tabular}

The differences in the geometric dimensions of the flame (computation-experiment) stem from the complexity of describing and simulating combustion processes, and the accuracy of determining the flame boundaries (zones) by experimental data. As concerns the macro indicators (main flame dimensions, temperature and NO concentration) for such complex processes, the error is within admissible limits.

The results in Figs. 4-5 and Table 2 demonstrate that the use of the standard $k-\varepsilon$ model turbulence model and the chosen adjustments of the parameters of the mathematical models yield acceptable numerical simulation results.

Based on the conducted research, further design simulations will use the standard $k-\varepsilon$ turbulence model [29-31]. They will involve numerical simulation of the combustion of the stoichiometric hydrogen-oxygen mixture in the auxiliary steam generator.

The flow part of the steam generator is a body of rotation (Fig. 6).

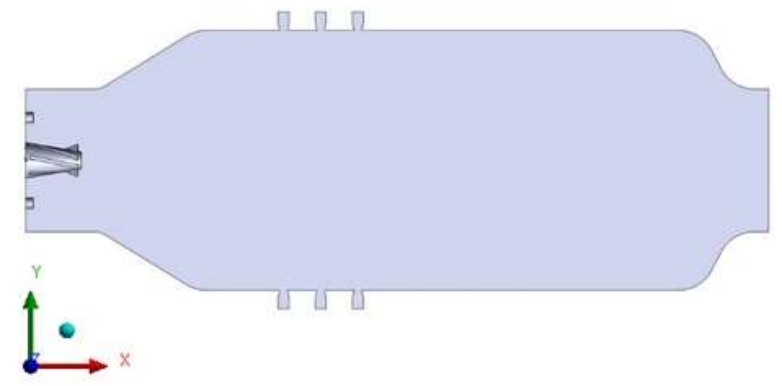

Figure 6. Cross-section view of the steam generator flow part

The flow part length is $200 \mathrm{~mm}$ and the diameter of the water-cooled $\mathrm{CC}$ is $75 \mathrm{~mm}$. A nozzles unit located $70 \mathrm{~mm}$ away from the $\mathrm{CC}$ is provided for feeding water to the steam generator.

To evaluate the influence of the discretization level and the increase of the accuracy of numerical simulation results, the paper considers three variants of the level of discretization of the computational domain. The computational cells used for numerical simulation are shown in Fig. 7 and their dimensions, in Table 3. 


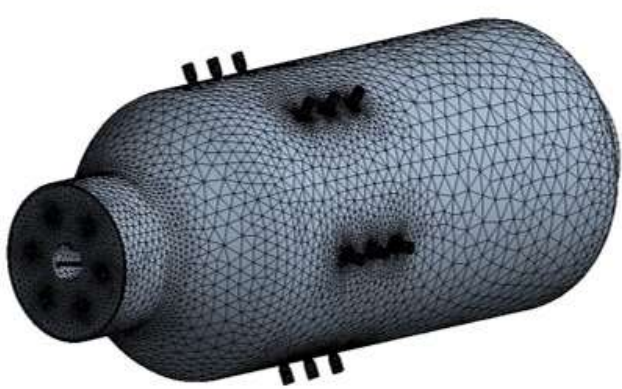

1

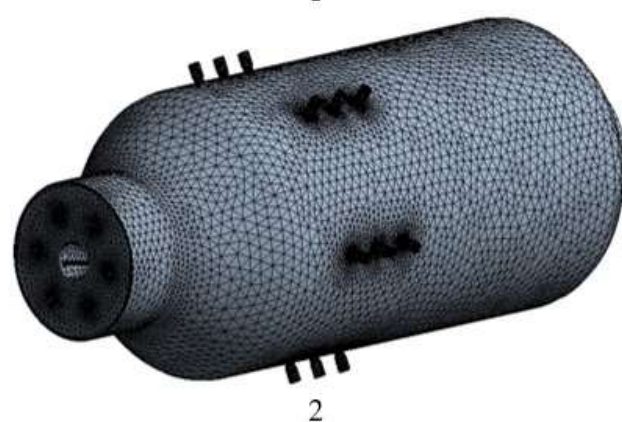

2

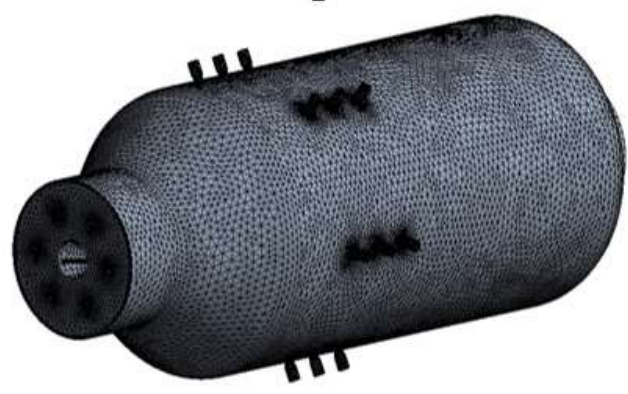

3

Figure 7. Numerical mesh for numerical simulation

Table 3. Number of numerical meshes with a different level of discretization of the computational domain

\begin{tabular}{|c|c|c|c|}
\hline Variant & 1 & 2 & 3 \\
\hline $\begin{array}{c}\text { Number of numerical } \\
\text { mesh cells, mln. }\end{array}$ & 0.381 & 0.515 & 1.02 \\
\hline
\end{tabular}

To increase the accuracy of modelling near-wall effects during the flow of the gases and their combustion, the numerical mesh was adapted in the papers [39-41]. This paper uses numerical meshes having five layers in the nearwall layer with a minimal cell height of $0.1 \mathrm{~mm}$.

The scheme for specifying boundary conditions (BC) is shown in Fig. 8, and the BC values are given in Table 4.

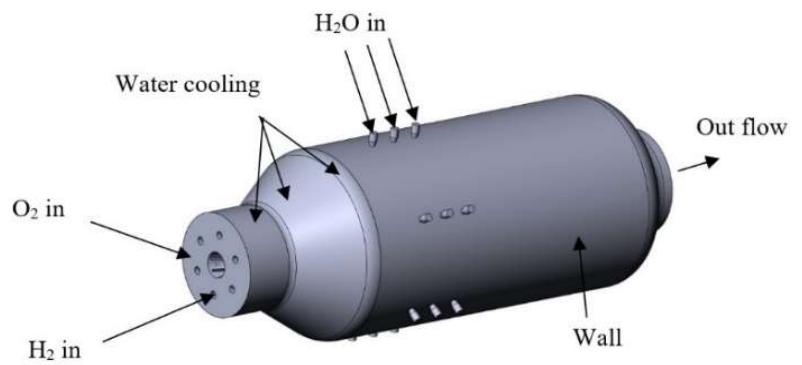

Figure 8. Scheme for specifying boundary conditions

Table 4. Values of boundary conditions

\begin{tabular}{|c|c|c|}
\hline Boundary & Boundary type & Value \\
\hline $\mathrm{O}_{2}$ in & Inlet velocity, $\mathrm{m} / \mathrm{s}$ & 5 \\
\cline { 2 - 3 } & Temperature, ${ }^{\circ} \mathrm{C}$ & 25 \\
\hline \multirow{2}{*}{$\mathrm{H}_{2}$ in } & Inlet velocity, $\mathrm{m} / \mathrm{s}$ & 160 \\
\cline { 2 - 3 } & Temperature, ${ }^{\circ} \mathrm{C}$ & 25 \\
\hline \multirow{2}{*}{$\mathrm{H}_{2} \mathrm{O}$ in } & Inlet velocity, $\mathrm{m} / \mathrm{s}$ & 120 \\
\cline { 2 - 3 } & Temperature, ${ }^{\circ} \mathrm{C}$ & 95 \\
\hline \multirow{2}{*}{ Tut flow } & $\begin{array}{c}\text { Excess pressure, } \mathrm{MPa} \\
\end{array}$ & 6 \\
\cline { 2 - 3 } & $\begin{array}{c}\text { Ambient temperature, } \\
{ }^{\circ} \mathrm{C}\end{array}$ & 500 \\
\hline \multirow{2}{*}{ Wall } & $\begin{array}{c}\text { Ambient temperature, } \\
{ }^{\circ} \mathrm{C}\end{array}$ & 25 \\
\cline { 2 - 3 } & $\begin{array}{c}\text { Heat transfer } \\
\text { coefficient, } \mathrm{W} /\left(\mathrm{m}^{2} \mathrm{~K}\right)\end{array}$ & 300 \\
\cline { 2 - 3 } & Wall roughness, $\mu \mathrm{m}$ & 30 \\
\hline
\end{tabular}

\section{Results}

The results of numerical simulation of the process of hydrogen combustion in oxygen with feed water in the steam generator flow part are shown in Figs. 9-12.

Fig. 9 shows the gas and flame temperature distributions. The maximum temperature is in the peripheral area of the combustion chamber, and it reaches $2,721{ }^{\circ} \mathrm{C}$. With distance from the combustion chamber, the temperature drops from 2,100 to $1,368^{\circ} \mathrm{C}$.

The irregularity of temperature distribution along the combustion chamber radius (Fig. 9b) is due to the swirl of the hydrogen-oxygen mixture flow. 

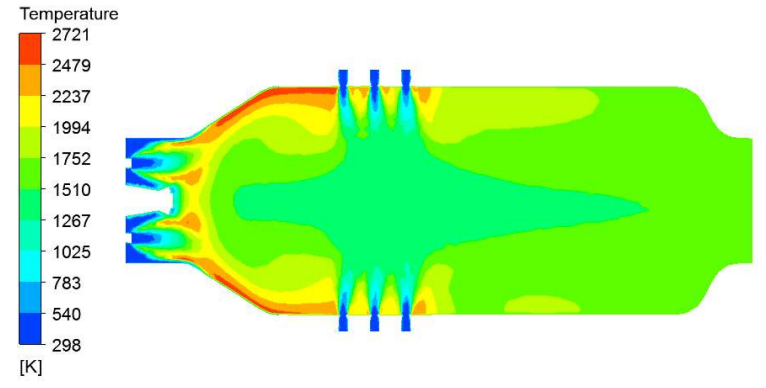

a)
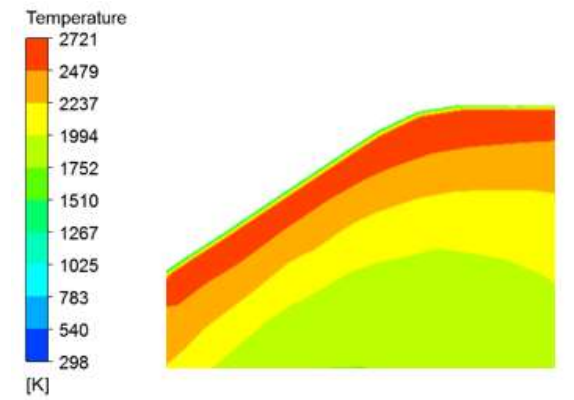

b)
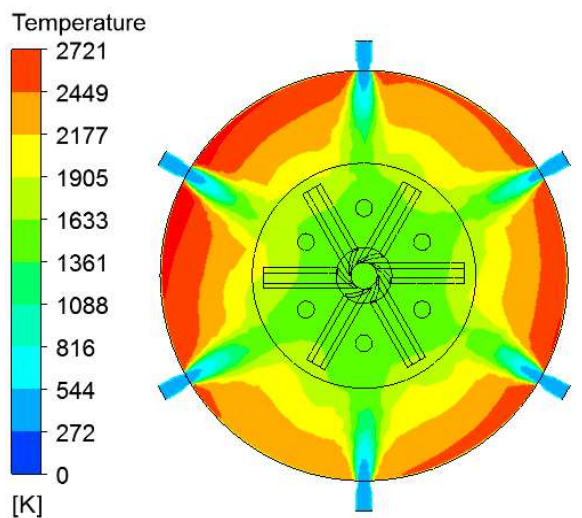

c)

Figure 9. Temperature distribution in the steam generator flow part during combustion of hydrogen in oxygen: a cross section along the steam generator axis; $b$ - magnified; $\mathrm{c}-$ cross section perpendicular to the steam generator axis.

The obtained temperature distribution in the combustion chamber volume is attributed to the action of water on the combustion process of the hydrogen-oxygen mixture. During interaction of the flame with the extra water, due to the contrast in density, the water drives the flame towards the walls, with the flame and water contact area having the shape of a deformed paraboloid (Fig. 10).

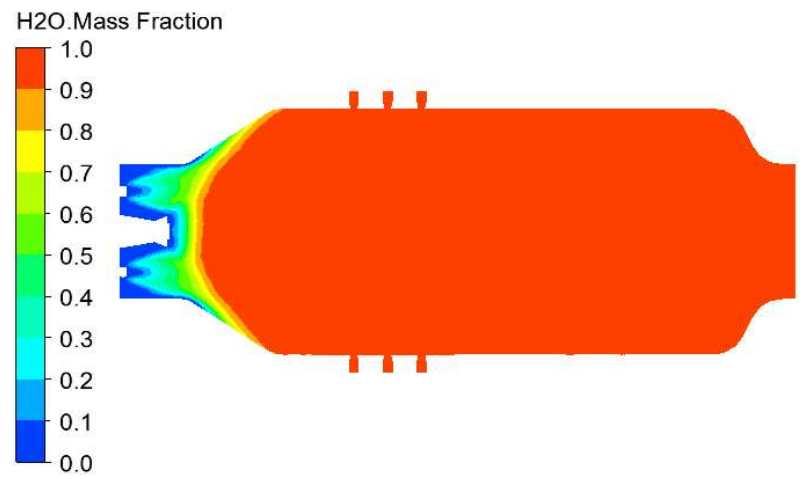

Figure 10. Distribution of the water steam mass fraction during the combustion of the hydrogen-oxygen mixture (along the steam generator axis)

A feature of the suggested steam generator design is the presence of a swirler at the inlet and the realisation of the combustion process within the limits of the forced water cooling of the combustion chamber (further, this water is fed to the steam generator through nozzles arranged perpendicularly to the generator's axis). This excludes flame extraction along the flow part axis and reduces irrecoverable heat losses through the walls to the environment.

In the wall layer, the gas and flame temperatures drop from $2,200 \mathrm{~K}$ to $1,120 \mathrm{~K}$.

With such a combustion mode, the maximum wall temperature does not exceed $850{ }^{\circ} \mathrm{C}$. This is not critical for the combustion chamber material - refractory steel.

Such a temperature distribution during combustion of the hydrogen-oxygen mixture is due to the presence of turbulent flows and the action of the feed water on the burning process (Fig. 11). 

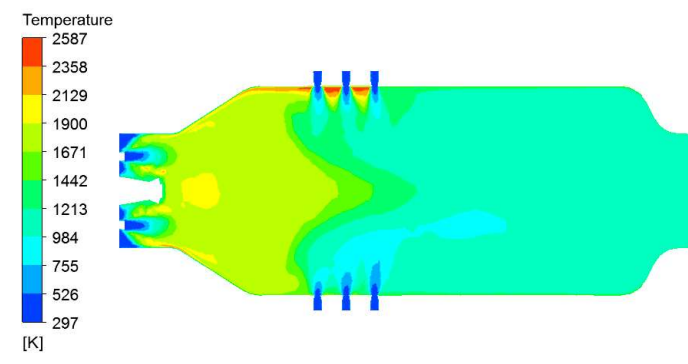

$\tau=0.02 \mathrm{~s}$
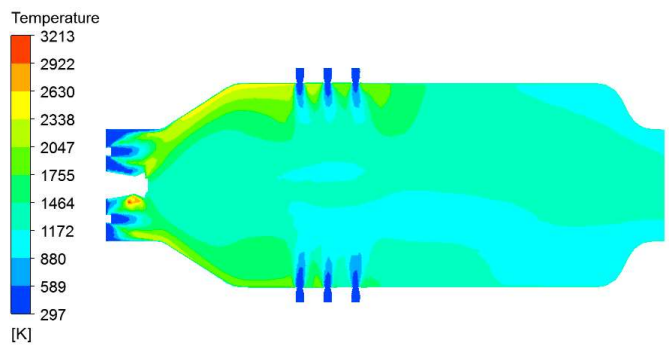

$\tau=0.04 \mathrm{~s}$
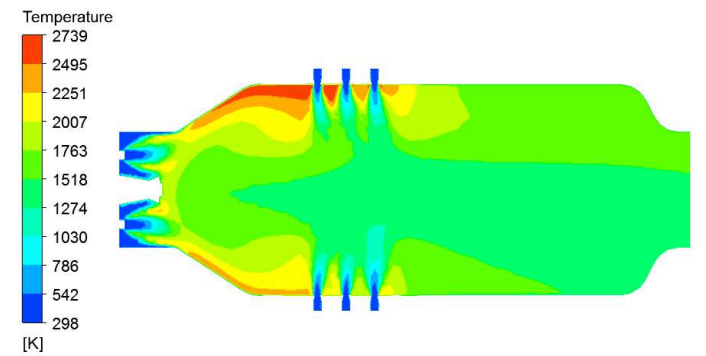

$$
\tau=0.1 \mathrm{~s}
$$
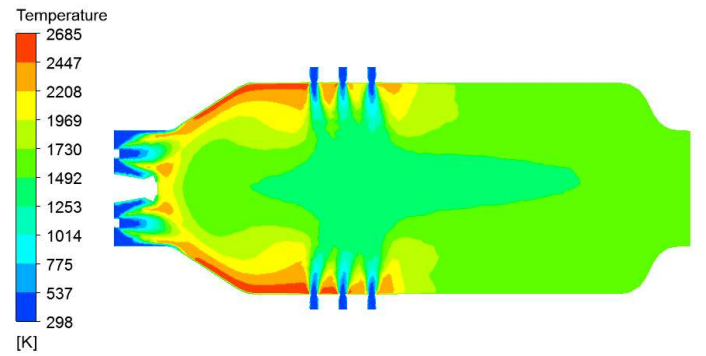

$\tau=0.16 \mathrm{~s}$
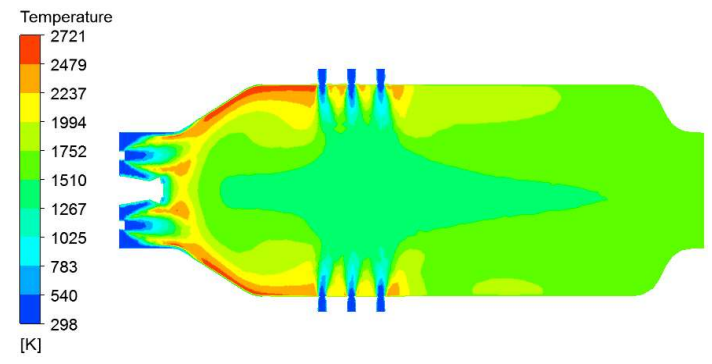

$$
\tau=5 \mathrm{~s}
$$

Figure 11. Turbulent flame pulsations during combustion of the hydrogen-oxygen mixture (along the steam generator axis)
The results (Fig. 11) show that the combustion process is stabilised in 5 seconds after its starting, with account of the small steam generator dimensions.

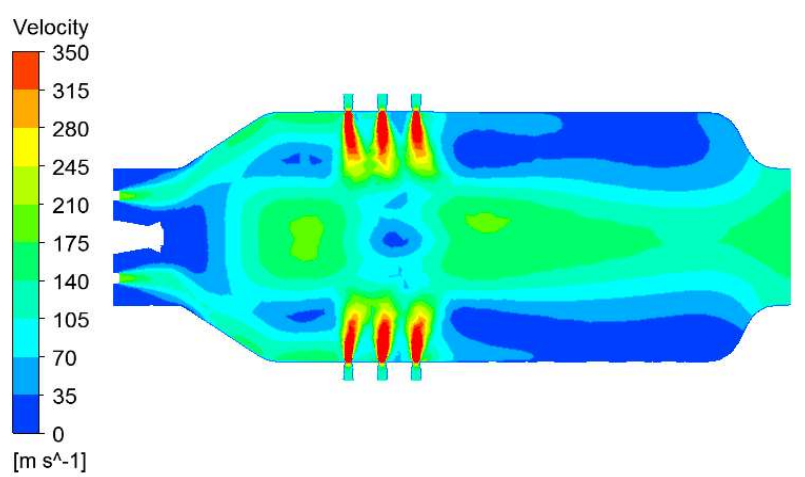

a)

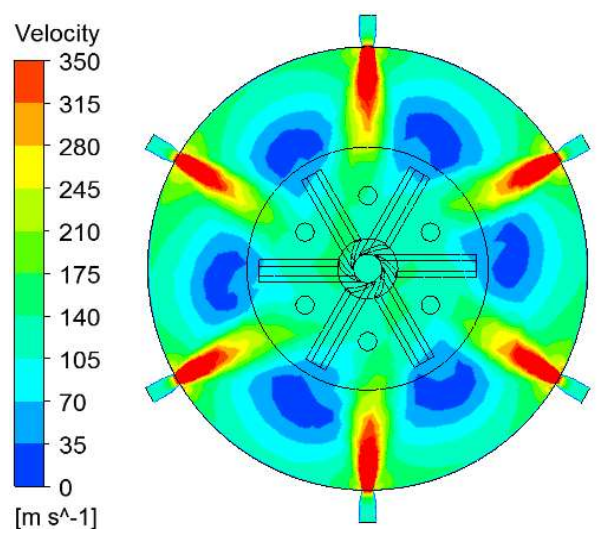

b)

Figure 12. Distribution of the flow velocity in the steam generator flow part during combustion of hydrogen in oxygen: $\mathrm{a}$ - cross section along the steam generator axis; $\mathrm{b}-$ cross section perpendicular to the steam generator axis.

The flow velocity distribution is shown in Fig. 12. The maximum velocity is in the zone of the water feed nozzles and it reaches $350 \mathrm{~m} / \mathrm{s}$. With distance from the water feed nozzles, the flow velocity drops from 220 to $105 \mathrm{~m} / \mathrm{s}$.

Such an irregular distribution of the flow velocity is the result of complex heat-and-mass transfer processes in the steam generator combustion chamber, and of the arrangement of the nozzles for feeding extra water. 
The extra water fed to the steam generator perpendicularly to its axis creates a curtain, with the flow being decelerated to reduce the velocity in the flow part central zone to $7.2 \mathrm{~m} / \mathrm{s}$ (Fig. 12 a).

The accuracy of the problem formulation and the solution was evaluated with account of the balance of masses at the steam generator inlet and outlet (Table 5).

Table 5. Mass balance at the gas burner inlet and outlet

\begin{tabular}{|c|c|c|c|}
\hline \multicolumn{3}{|c|}{ Inlet flow } & Out flow \\
\hline $\mathrm{O}_{2}$ & $\mathrm{H}_{2}$ & $\mathrm{H}_{2} \mathrm{O}$ & All fluid \\
\hline $\mathrm{kg} / \mathrm{s}$ & $\mathrm{kg} / \mathrm{s}$ & $\mathrm{kg} / \mathrm{s}$ & $\mathrm{kg} / \mathrm{s}$ \\
\hline 0.005 & 0.000687 & 0.0263 & 0.0317 \\
\cline { 1 - 1 } All fluid: $0.0319 \mathrm{~kg} / \mathrm{s}$ & \\
\hline
\end{tabular}

The results in Table 5 show that it was possible to achieve good agreement of flow rates at the inlet and outlet of the steam generator. This is indicative of an accurate problem formulation. The mass imbalance between the inlet and outlet is within $0.63 \%$.

\section{Discussion}

The influence of the discretization level on the numerical simulation results is shown in Table 6.

Table 6. The influence of the level of discretization on numerical simulation results

\begin{tabular}{|c|c|c|c|}
\hline $\begin{array}{c}\text { Number of } \\
\text { computational } \\
\text { cells, mln. }\end{array}$ & $\begin{array}{c}\text { Maximum } \\
\text { temperature, } \\
{ }^{\circ} \mathrm{C}\end{array}$ & $\begin{array}{c}\text { Water } \\
\text { steam } \\
\text { temperature } \\
\text { at steam } \\
\text { generator } \\
\text { outlet, }{ }^{\circ} \mathrm{C}\end{array}$ & $\begin{array}{c}\text { Mass } \\
\text { fraction } \\
\text { of } \\
\text { hydrogen } \\
\text { at steam } \\
\text { generator } \\
\text { outlet }\end{array}$ \\
\hline 0.381 & 2,755 & 1,391 & 0.00152 \\
\hline 0.515 & 2,728 & 1,375 & 0.00157 \\
\hline 1.02 & 2,721 & 1,368 & 0.00168 \\
\hline
\end{tabular}

The results in Table 6 demonstrate that the further increase of the number of computational cells (over 1 million) is impractical and leads to a growth of problem dimensionality without a substantial increase in the accuracy of numerical simulation results. The maximum temperature difference with a 3-fold increase of the discretization level is $1.2 \%$.

The estimates of the effect of the feed water flow rate on the combustion process in the steam generator are shown in Table 7 and Fig.13.

Table 7. The effect of the feed water flow rate on the combustion process in the steam generator

\begin{tabular}{|c|c|c|c|c|}
\hline № & $\begin{array}{c}\text { Steam } \\
\text { generator } \\
\text { feed } \\
\text { water } \\
\text { mass } \\
\text { flow }\end{array}$ & $\begin{array}{c}\text { Steam } \\
\text { mass } \\
\text { flow }\end{array}$ & $\begin{array}{c}\text { Steam } \\
\text { temperature } \\
\text { at steam } \\
\text { generator } \\
\text { outlet }\end{array}$ & $\begin{array}{c}\text { Mass } \\
\text { fraction } \\
\text { of } \\
\text { hydrogen } \\
\text { at steam } \\
\text { generator } \\
\text { outlet }\end{array}$ \\
\cline { 2 - 5 } & $\mathrm{G}_{\mathrm{H} 2 \mathrm{O}}$ & $\mathrm{G}_{\text {st }}$ & $\mathrm{T}_{\text {st }}$ & $\mathrm{H}_{2 \mathrm{MF}}$ \\
\cline { 2 - 5 } & $\mathrm{kg} / \mathrm{s}$ & $\mathrm{kg} / \mathrm{s}$ & $\mathrm{K}$ & - \\
\hline 1 & 0.0061 & 0.012 & 2,650 & 0.00121 \\
\hline 2 & 0.0094 & 0.0157 & 2,230 & 0.00151 \\
\hline 3 & 0.0263 & 0.0317 & 1,368 & 0.00168 \\
\hline 4 & 0.168 & 0.174 & 576 & 0.00250 \\
\hline 5 & 0.529 & 0.530 & 495 & 0.00274 \\
\hline
\end{tabular}

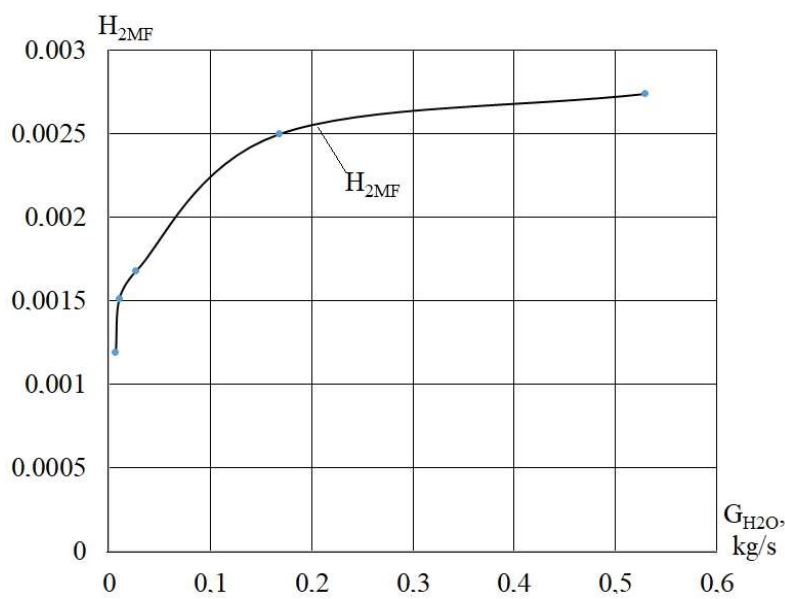

Figure 13. The influence of the feed water flow rate on the discharge of the hydrogen mass fraction with reaction products during combustion of the hydrogen-oxygen mixture in the steam generator

The results in Table 7 and Fig. 13 show that an increase in the mass flow rate of the steam 
generator feed water to over $0.0317 \mathrm{~kg} / \mathrm{s}$ leads to a reduced fuel efficiency and a sharp steam temperature drop. This is explained by the increase in the heat capacity of the steam-and-gas mixture (with an increased steam content) and the expenditure of much energy on water evaporation and heating, with an adverse effect on combustion efficiency.

This also has an adverse effect on the performance of the system for feeding extra steam to the steam turbine intermediate pressure stage.

The paper considers other steam generator design variants as an alternative to the suggested construction (Fig. 14).

Numerical simulation results were obtained using identical mathematical models and source data (Figs. 15-20).

Fig. 15 illustrates the flame temperature distribution along the steam generator axis.

The maximum temperature is in the central area of the steam generator and it reaches 2,739 K. Close to the combustion chamber walls, the temperature varies from 2,000 to $1,500 \mathrm{~K}$.

Fig. 16 illustrates the flow velocity distribution along the steam generator axis.

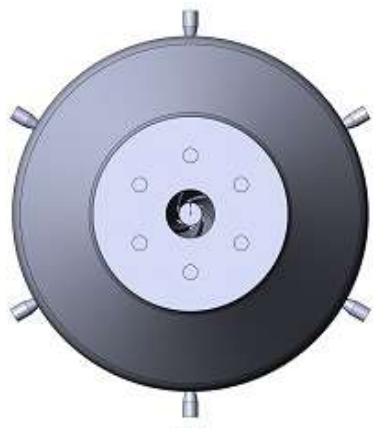

1)

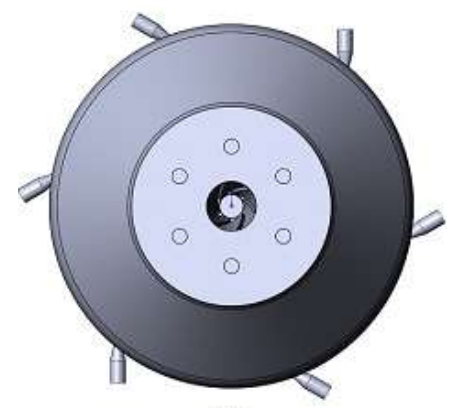

2)

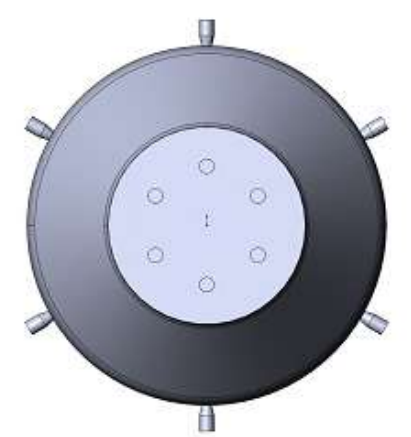

3)

Figure 14. Steam generator design variants: 1 - baseline; 2 - tangential water feed; 3 - without a swirler

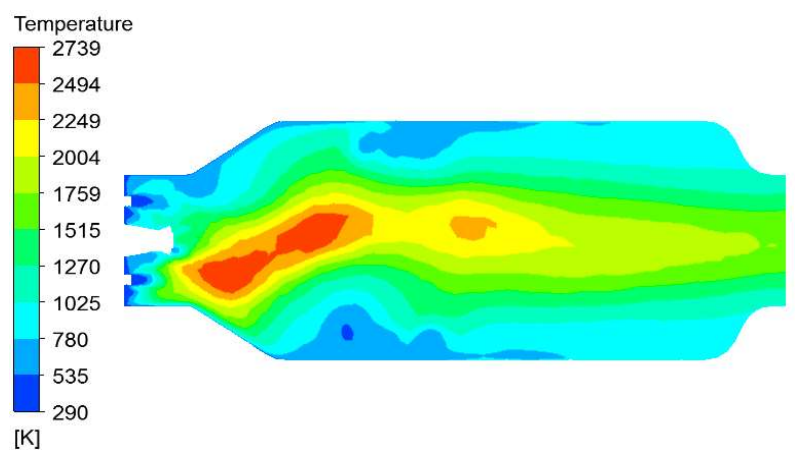

Figure 15. Temperature distribution in the steam generator flow part during combustion of hydrogen in oxygen (design variant 2) 

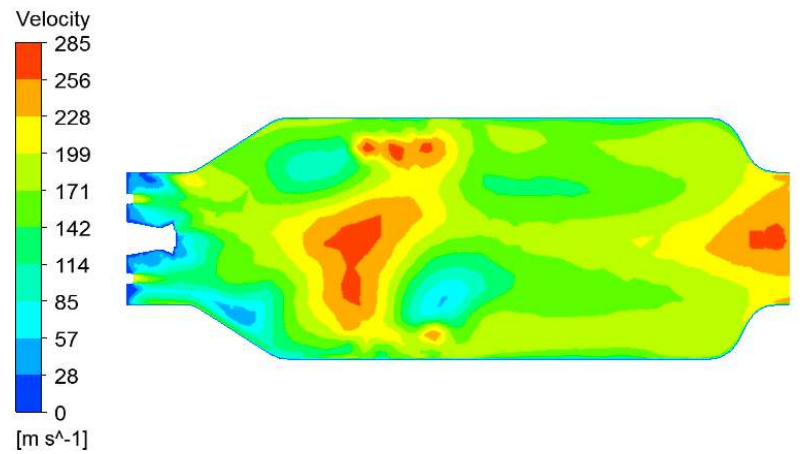

Figure 16. Distribution of the flow velocity in the steam generator flow part during combustion of hydrogen in oxygen (design variant 2)

The maximum velocity reaches $285 \mathrm{~m} / \mathrm{s}$ in the central part of the steam generator (Fig. 16). Due to the involved design and the proceeding processes, the flow velocity distribution is irregular.

Distribution of the steam mass share in the process of combustion of the hydrogenoxygen mixture is shown in Fig. 17.

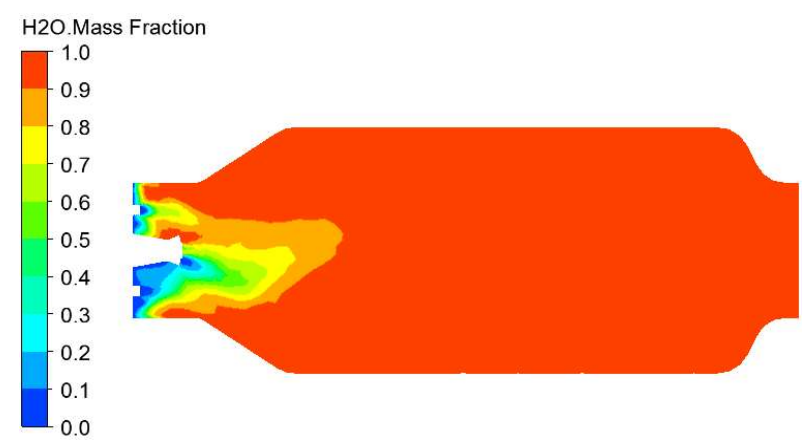

Figure 17. Distribution of the steam mass share in the process of combustion of the hydrogen-oxygen mixture, along the steam generator axis (design variant 2)

Flame extension and the formation of an isosurface on the flame-steam interface along the flow part axis is the result of emergence of a lowdensity steam-gas mixture in the central zone through which the flame spreads.

Such a combustion mode is accompanied by hydrogen afterburning beyond the cooled part of the combustion chamber and declining fuel combustion efficiency.

Figures 18-20 show the isosurfaces of the mass share of the steam $\mathrm{MF}_{\mathrm{H} 2 \mathrm{O}}=0.99$ and the distribution of local temperatures for three steam generator design variants.

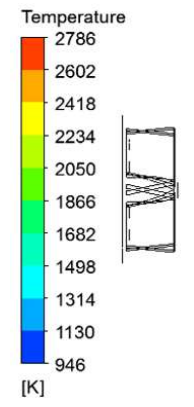

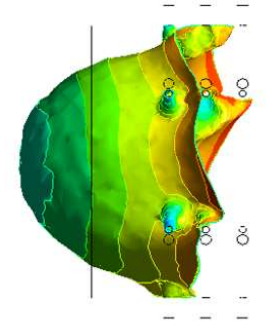

a)

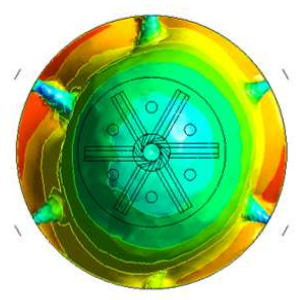

b)
Figure 18. Isosurface of the steam mass share $\mathrm{MF}_{\mathrm{H} 2 \mathrm{O}}=$ 0.99 and the distribution of local temperatures (design variant 1$)$ : $a$ - side view; $b$ - frontal view

The results show (Fig. 18) that the isosurface has the form of a deformed paraboloid facing the swirler. The isosurface deformation is the result of the action of the oxygen and hydrogen flow. The maximum temperature reaches $2,283 \mathrm{~K}$ in the isosurface base zone. In the apex zone, the temperature varies from 1,500 to $1,800 \mathrm{~K}$.

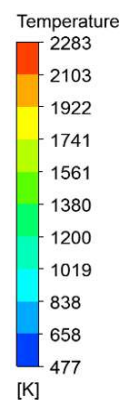

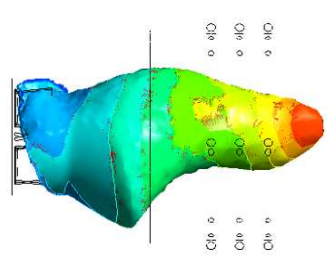

a)

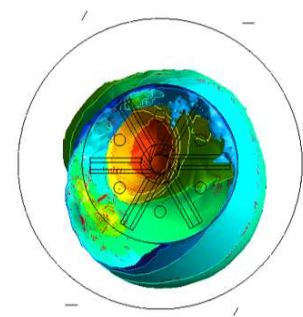

b)
Figure 19. Isosurface of the steam mass share $\mathrm{MF}_{\mathrm{H} 2 \mathrm{O}}=0.99$ and the distribution of local temperatures (design variant 2 ): $a$ - side view; $b$ - frontal view 
For design variant 2 (Fig. 19), the isosurface form is a deformed cylinder facing the steam generator outlet orifice. Such a direction and isosurface form are the result of tangential feed of extra water and the occurrence of a steamand-gas interspace in the centre of the steam generator flow part, through which the flame spreads.

The maximum temperature reaches 2,283 $\mathrm{K}$ in the isosurface base zone. The temperature varies from 2,000 to $477 \mathrm{~K}$ along the isosurface length.

Fig. 20 shows the isosurface of the steam mass share for design variant 3 .

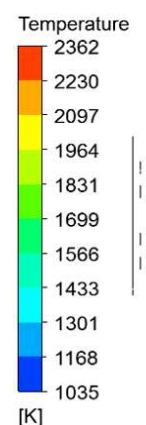

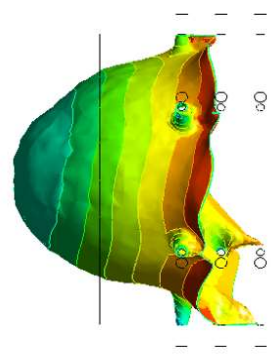

a)

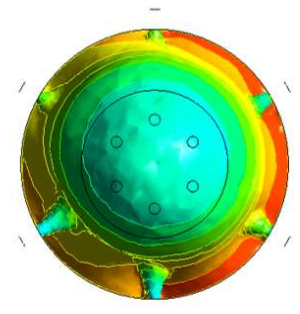

b)
Figure 20. Isosurface of the steam mass share $\mathrm{MF}_{\mathrm{H} 2 \mathrm{O}}=$ 0.99 and the distribution of local temperatures (design variant 3): $\mathrm{a}$ - side view; $\mathrm{b}$ - frontal view

The form and orientation of the isosurface resembles that for design variant 1 , though with smaller deformation of the base. This is due to absence of a swirler. The maximum temperature is at the isosurface base and reaches 2,362 K (Fig. 20). In the apex zone, the temperature varies from 1,300 to $1,800 \mathrm{~K}$.

Tables 8 and 9 show the results of numerical simulation of the effect of steam generator design parameters on the process of the combustion of the hydrogen-oxygen mixture.

Table 8. Effect of the steam generator design on the parameters of the flame-steam interface

\begin{tabular}{|c|c|c|c|}
\hline $\begin{array}{c}\text { Design } \\
\text { variant, } \\
\text { No. }\end{array}$ & $\begin{array}{c}\mathrm{S}_{\mathrm{c}}{ }^{*}, \\
\mathrm{~m}^{2} / *\end{array}$ & $\begin{array}{c}\mathrm{T}^{* * *}, \\
\mathrm{~K} / * *\end{array}$ & $\begin{array}{c}\text { Mass share } \\
\text { of } \mathrm{H}_{2} \text { on } \\
\text { the flame- } \\
\text { steam } \\
\text { interface/** }\end{array}$ \\
\hline 1 & $0.0099 /-$ & $2,071 /-$ & $0.00385 /-$ \\
\hline 2 & $0.0115 / 16$ & $1,056 / 49$ & $0.00403 / 4.9$ \\
\hline 3 & $0.0099 / 0$ & $1,896 / 8.5$ & $0.00438 / 14$ \\
\hline
\end{tabular}
percentage change $(\%) ; * * *$ - averaged isosurface temperature on the flame-steam interface.

Table 8 shows that the best conditions for realising an effective hydrogen-oxygen mixture combustion process belong to design variant 1 . With a minimal flame-steam area of contact, it has the highest temperature on the interface and the lowest mass share of unburnt hydrogen.

Table 9. Effect of the steam generator design on the combustion mode (the mode with the steam flow rate $\mathrm{G}_{\mathrm{st}}$

\begin{tabular}{|c|c|c|c|c|}
\hline $\begin{array}{c}\text { Design } \\
\text { variant, } \\
\text { No. }\end{array}$ & $\begin{array}{c}\text { Maxim } \\
\text { um } \\
\text { temper } \\
\text { ature, } \\
{ }^{\circ} \mathrm{C} / *\end{array}$ & $\begin{array}{c}\text { Gas } \\
\text { temperat } \\
\text { ure in the } \\
\text { interface } \\
\text { layer, K }\end{array}$ & $\begin{array}{c}\text { Water } \\
\text { steam } \\
\text { temperat } \\
\text { ure at the } \\
\text { steam } \\
\text { generato } \\
\text { r outlet, } \\
{ }^{\circ} \mathrm{C} / *\end{array}$ & $\begin{array}{c}\text { Share of } \\
\text { unburnt } \\
\text { fuel }(\%), / *\end{array}$ \\
\hline 1 & $2,721 /-$ & $1,120 /-$ & $1,368 /-$ & $7.7 /-$ \\
\hline 2 & $2,739 /$ & $780 / 30$ & $1,178 / 14$ & $10 / 30$ \\
\hline 3 & $2,528 /$ & $1,00 / 9$ & $1,379 / 0$. & $8,7 / 13$ \\
& & & 8 & \\
\hline
\end{tabular}
* - percentage change (\%).

Table 9 shows that the most effective steam generator design variant is No. 1. Its maximum flame temperature reaches $2,721 \mathrm{~K}$ and in the interface layer, it is within $1,120 \mathrm{~K}$. The unburnt fuel share is within $7.7 \%$, and this in agreement with the results of other authors [42]. 
The biggest unburnt fuel share (10\%) was found in design variant 2 . This is the result of flame extension along the flow part length and fuel afterburning under unfavourable conditions.

\section{Conclusions}

The research yielded the following results:

- the standard $k-\varepsilon$ turbulence model yields informative results during the simulation of the process of combustion of the stoichiometric hydrogen-oxygen mixture with a high rate and pressures in both the wall areas and the central zone of the steam generator;

- during combustion of the stoichiometric hydrogen-oxygen mixture in the steam generator with water feed the flame temperature reaches $2,721^{\circ} \mathrm{C}$ in the peripheral area of the combustion chamber. This is due to the turbulence of the fuel and oxidizer flow and the effect of feeding extra water.

- increasing the mass flow of the steam generator feed water to over $0.0317 \mathrm{~kg} / \mathrm{s}$ reduces the steam temperature lower than the admissible limits (less than $1,300 \mathrm{~K}$ ). This results in an increasing share of unburnt fuel at the steam generator outlet.

- the research has shown that design variant 1 with inlet flow turbulisation (with a swirler installed) and extra water feed in a direction perpendicular to the steam generator axis combines high steam generation capacity $(0.0412 \mathrm{~kg} / \mathrm{s}$ for a 1 -litre steam generator) with an acceptable steam temperature $(1,368 \mathrm{~K})$ and a minimal share of unburnt fuel $(7.7 \%)$, with the temperature of the water-cooled combustion chamber walls not exceeding $850^{\circ} \mathrm{C}$;

- the research results can be used to predict the performance indices of hydrogen-oxygen steam generators and improve them.

- as a fuel, hydrogen has a significant potential in both the power industry and transport. The challenging issues are generation systems (with low energy consumption levels), and storage and usage (direct firing and oxidation in fuel cells).

Funding: The work is fulfilled according to the program-oriented and competitive themes of the National Academy of Ukraine, N 2-86-2/II-1420, titled "Developing the Methods to Increase the Efficiency of the Power Units of Thermal Power Stations by Applying the Steam-Gas Technologies".

\section{References}

[1] Öztuna S, Büyükakın M. Effects of hydrogen enrichment of methane on diffusion flame structure and emissions in a back-pressure combustion chamber. International Journal of Hydrogen Energy 2020;45(10):5971-5986.

[2] Iavarone S, Cafiero M, Ferrarotti M, Contino F, Parente A. A multiscale combustion model formulation for $\mathrm{NOx}$ predictions in hydrogen enriched jet flames. International Journal of Hydrogen Energy 2019;44(41):23436-23457.

[3] Benaissa S, Adouane B, Ali S, Mohammad A. Effect of hydrogen addition on the combustion characteristics of premixed biogas/hydrogen-air mixtures. International Journal of Hydrogen Energy 2021;46(35):18661-18677. [4] Prasad T, Jithin E, Varghese R, Kumar S, Mohammad A, Velamati R. Effect of hydrocarbon addition on tip opening of hydrogen-air bunsen flames. International Journal of Hydrogen Energy 2021;46(7):5763-5775 
[5] Burke M, Chaos M, Ju Y, Dryer F, Klippenstein S. Comprehensive $\mathrm{H} 2 / \mathrm{O} 2$ kinetic model for high-pressure combustion. International Journal of Chemical Kinetics 2011;44(7):444-474.

[6] Wallner T, Matthias N, Scarcelli R, Kwon J. Evaluation of the efficiency and the drive cycle emissions for a hydrogen direct-injection engine. Proceedings of the Institution of Mechanical Engineers, Part D: Journal of Automobile Engineering 2012;227(1):99-109.

[7] Tanneberger T, Stathopoulos P. Heat transfer measurements in a hydrogen-oxyfuel combustor. Experimental Heat Transfer 2020;34(7):620-638.

[8] Tanneberger T, Schimek S, Paschereit C, Stathopoulos P. Efficiency Measurement Approach for a Hydrogen Oxyfuel Combustor. Journal of Engineering for Gas Turbines and Power 2019;141(10):101023.

[9] Tanneberger T, Schimek S, Paschereit C, Stathopoulos

P. Combustion efficiency measurements and burner characterization in a hydrogen-oxyfuel combustor. International Journal of Hydrogen Energy 2019;44(56):29752-29764.

[10] Zhukov V. Verification, Validation, and Testing of Kinetic Mechanisms of Hydrogen Combustion in FluidDynamic Computations. ISRN Mechanical Engineering 2012;2012:1-11

[11] Calili F, Ismail M, Ingham D, Hughes K, Ma L, Pourkashanian M. A dynamic model of air-breathing polymer electrolyte fuel cell (PEFC): A parametric study. International Journal of Hydrogen Energy 2021;46(33):17343-17357

[12] Solovey V, Khiem N, Zipunnikov M, Shevchenko A. Improvement of the Membrane - less Electrolysis Technology for Hydrogen and Oxygen Generation. French-Ukrainian Journal of Chemistry 2018;6(2):73-79. [13] Borzenko V, Schastlivtsev A. Efficiency of Steam Generation in a Hydrogen-Oxygen Steam Generator of Kilowatt-Power Class. High Temperature 2018;56(6):927932.
[14] Alabbadi S. Hydrogen Oxygen Steam Generator Integrating with Renewable Energy Resource for Electricity Generation. Energy Procedia 2012;29:12-20.

[15] Aminov R, Egorov A. Study of Hydrogen Combustion in an Oxygen Environment. High Temperature 2018;56(5):744-750.

[16] Turányi T, Tomlin A. Reduction of Reaction Mechanisms. Analysis of Kinetic Reaction Mechanisms 2014:183-312.

[17] Varga T, Nagy T, Olm C, Zsély IGy, Pálvölgyi R, Valkó É, Vincze G, Cserháti M, Curran HJ, Turányi T. Optimization of a hydrogen combustion mechanism using both direct and indirect measurements. Proceedings of the Combustion Institute 2015;35(1):589-596.

[18] Varga T, Olm C, Nagy T, Zsély IGy, Valkó É, Pálvölgyi R, Curran HJ, Turányi T. Development of a Joint Hydrogen and Syngas Combustion Mechanism Based on an Optimization Approach. International Journal of Chemical Kinetics. 2016:48(8):407-422.

[19] Olm C, Zsély IGy, Pálvölgyi R, Varga T, Nagy T, Curran HJ, Turányi T. Comparison of the performance of several recent hydrogen combustion mechanisms. Combustion and Flame 2014;161(9):2219-2234.

[20] Dounia O, Vermorel O, Misdariis A, Poinsot T. Influence of kinetics on DDT simulations. Combustion and Flame 2019;200:1-14.

[21] Boushaki T, Dhué Y, Selle L, Ferret B, Poinsot T. Effects of hydrogen and steam addition on laminar burning velocity of methane-air premixed flame: Experimental and numerical analysis. International Journal of Hydrogen Energy 2012;37(11):9412-9422.

[22] Rusanov A, Shubenko A, Senetskyi O, Babenko O, Rusanov R. Heating modes and design optimization of cogeneration steam turbines of powerful units of combined heat and power plant. Energetika 2019;65(1):39-50.

[23] Zipunnikov M, Bukhkalo S, Kotenko A. Researching The Process Of Hydrogen Generating From Water With The Use Of The Silicon Basis Alloys. French-Ukrainian Journal of Chemistry 2019;7(2):138-144. 
[24] Erete J, Hughes K, Ma L, Fairweather M, Pourkashanian M, Williams A. Effect of $\mathrm{CO} 2$ dilution on the structure and emissions from turbulent, non-premixed methane-air jet flames. Journal of the Energy Institute 2017;90(2):191-200.

[25] Skrebkov O, Karkach S. Vibrational nonequilibrium and electronic excitation in the reaction of hydrogen with oxygen behind a shock wave. Kinetics and Catalysis 2007;48(3):367-375

[26] Büyükakın M, Öztuna S. Study on nonpremixed methane/air combustion from flame structure and NOX emission aspect for different burner head structures. International Journal of Energy Research 2019;43(10):5421-5437.

[27] Bidi M, Hosseini R, Nobari M. Numerical analysis of methane-air combustion considering radiation effect. Energy Conversion and Management 2008;49(12):36343647.

[28] Poinsot T., Veynante D. Theoretical and Numerical Combustion, R.T. Edwards Inc, 2005, P. 522.

[29] Avramenko A. The impact of oxidiser humidity on methane combustion in a gas burner. French-Ukrainian Journal of Chemistry 2020;8(2):48-59.

[30] Yilmaz H, Cam O, Tangoz S, Yilmaz I. Effect of different turbulence models on combustion and emission characteristics of hydrogen/air flames. International Journal of Hydrogen Energy 2017;42(40):25744-25755. [31] Benim A, Pfeiffelmann B. Comparison of Combustion Models for Lifted Hydrogen Flames within RANS Framework. Energies 2019;13(1):152.

[32] Korkodinov IA. The Review of set of k- $\varepsilon$ models for modeling turbulence. Perm National Research Politechnic University 2013:5-16.

[33] On-line resource:

https://ansyshelp.ansys.com/account/secured?returnurl=/ Views/Secured/corp/v211/en/cfx_thry/i1396257.html

[34] Ferreira D, Arnao J, Moreira B, Rangel L, Park S. The impact of radiation in the gas combustion model for sugarcane bagasse grate boiler. Brazilian Journal of Chemical Engineering 2016;33(3):617-626.
[35] Shokrian A, Mobli H, Akbarnia A, Jafari A, Mousazade H, Zhu B. Application an Euler-Euler Multiphase-Flow Model for Simulation Flow in a Centrifugal Separator Machine. American Journal of Fluid Dynamics 2018;8(4):112-115.

[36] Launder B, Spalding D. The numerical computation of turbulent flows. Computer Methods in Applied Mechanics and Engineering 1974;3(2):269-289.

[37] Bleyer A, Taveau J, Djebaïli-Chaumeix N, Paillard C, Bentaïb A. Comparison between FLACS explosion simulations and experiments conducted in a PWR Steam Generator casemate scale down with hydrogen gradients. Nuclear Engineering and Design 2012;245:189-196.

[38] Halouane Y, Dehbi A. CFD simulations of premixed hydrogen combustion using the Eddy Dissipation and the Turbulent Flame Closure models. International Journal of Hydrogen Energy 2017;42(34):21990-22004.

[39 Prieler R, Demuth M, Spoljaric D, Hochenauer C. Evaluation of a steady flamelet approach for use in oxyfuel combustion. Fuel 2014;118:55-68.

[40] Huang W, Ma L, Pourkashanian M, Ingham D, Luo S, Liu J, Wang Z. Flow-Field Analysis of a Typical Hydrogen-Fueled Dual-Mode Scramjet Combustor. Journal of Aerospace Engineering 2012;25(3):336-346. [41] Salim M, Cheah S. Wall y+ strategy for dealing with wall-bounded turbulent flows. Int. MultiConf. Eng. Comput. Sci. (IMECS), 2009;2:1-6.

[42] Aboje A, Hughes K, Ingham D, Ma L, Williams A, Pourkashanian M. Numerical study of a wake-stabilized propane flame in a cross-flow of air. Journal of the Energy Institute 2017;90(1):145-158. 